\title{
Research on Innovation Promotion and Application of Guangzhou New Energy Automobile Industry
}

\author{
Xueyu Zhang ${ }^{1, *}$, Wenyong $\mathrm{Li}^{1}$ \\ ${ }^{1}$ Huali College Guangdong University of Technology, Guagzhou, China
}

\begin{abstract}
The new energy automobile industry has now formed a complete industrial chain. The cities in the Bay Area have a clear division of labor, sufficient technical reserves, and strong policy support. They are emerging industries that are mainly supported.With the continuous upgrading and transformation of the industry, the transformation and upgrading of the Guangzhou automobile industry is on the agenda. This paper discusses the current situation and problems of Guangzhou automobile industry. Analysis of Several Important Influencing Factors of Guangzhou Automobile Industry Innovation in Transformation and Upgrading. Through multi-factor comparison and data analysis, this paper puts forward the corresponding optimization path, in order to accelerate the transformation , upgrading of Guangzhou automobile industry innovation ecosystem and improve the incentive mechanism of Guangzhou new energy automobile industry innovation.
\end{abstract}

\section{Introduction}

"Energy-saving and New Energy Vehicle Technology Roadmap (Version 2.0)" and "New Energy Automobile Industry Development Plan (2021-2035)" released one after another,clarified the timing of the development of China's new energy vehicles, including hybrid vehicles and pure electric vehicles.In 2035, new energy vehicles will account for more than $50 \%$. As one of the national central cities, Guangzhou is in the forefront of automobile production and ownership. The automobile industry has become the pillar of Guangzhou's national economy.The annual output of local automobiles accounts for about $10 \%$ of the country's total output. It is expected that the automobile industry will continue to be an important engine for Guangzhou's economic and social development for a long time to come. New energy vehicles will replace traditional vehicles as a new means of transportation. Guangzhou's acceleration of the promotion and application of new energy vehicles can increase the scale of local brand new energy vehicles in the market and promote local vehicle companies.

\section{Discussion on Innovation, Transformation and Upgrading of Guangzhou's New Energy Industry}

\subsection{The necessity of the promotion and application of new energy vehicles in Guangzhou}

New energy automobile technology is different from traditional automobile technology and is a disruptive innovation of automobile technology. Guangzhou has a huge economic volume and population scale, rapid social and economic development and huge demand for automobiles, which has led to a double crisis of heavy dependence on oil and environmental pollution.New energy vehicles are low-noise, low-pollution or zeroemission vehicles. Accelerating the promotion, application and popularization of new energy vehicles is an important guarantee for alleviating energy dependence and urban atmospheric pressure, creating green homes, and enhancing urban competitiveness.

Guangzhou automobile industry is strong in traditional automobile technology, but its development speed is relatively backward compared with cities such as Shanghai, Beijing, and Shenzhen. The production capacity of new energy vehicles is mainly manifested by insufficient core technology mastery, insufficient application effects and relatively weak overall competitiveness. Guangzhou's acceleration of the promotion and application of new energy vehicles can effectively drive local new energy vehicle companies to increase the research and development of major key technologies and build a new source of automotive technology innovation center, which can promote the development of Guangzhou from traditional vehicles to leading the world's new energy vehicles City.

\footnotetext{
*Corresponding author: 546111699@qq.com
} 


\subsection{The necessity of the promotion and application of new energy vehicles in Guangzhou}

The strength of Guangzhou's new energy automobile industry from core components to vehicle production is relatively weak, lack of core technology research,development capabilitiesand insufficient branding of local enterprises. Compared with leading domestic new energy automobile manufacturers, there is a big gap in competitiveness. According to data from China Battery Network, the top 10 domestic power battery installed capacity rankings from January to December 2020 accounted for as much as 91.8\%. Guangzhou's local power battery manufacturers such as Penghui Energy, Yiwei Energy and other companies only Guangzhou Penghui Energy can enter the top 20. In addition, Guangzhou Nengxinyuan Automobile's technical strength in drive motor companies is relatively weak, and its market competitiveness is relatively insufficientIn terms of suppliers of electronic control systems for new energy vehicles, none of the leading domestic companies are local companies in Guangzhou. The business operation model of new energy vehicles in Guangzhou is relatively simple, and the time-sharing leasing model of new energy vehicles has not formed a market scale, and there are great lags and limitations. In the operation process, there are few parking spaces and insufficient charging piles. Users cannot find a place to park or need to use manual scheduling to send the vehicle to the charging pile outlet for charging. In the face of sudden problems that cannot be dealt with in a timely manner, which brings great inconvenience to users, the public still has a little understanding of their level of awareness.

\subsection{Guangzhou government promotes the promotion and application of new energy vehicles}

The promotion and application of new energy vehicles in Guangzhou is still in its infancy and it is already at a backward stage compared to other first-tier cities. From the policy research at the national and local levels of Guangzhou, the government has always supported the promotion and application of new energy vehicles in the purchase subsidy policy.Charging facility management policy, tax management policy, public sector procurement policy, and licensing policy. Policies, the government can play a positive role in promoting the application of new energy vehicles. Government departments are authoritative and statutory. They are the top-level designers in the development of Xinyuan Automobile, formulating basic guidelines for the promotion and application of new energy vehicles, ensuring the government's guidance for the standardized development of new energy vehicles, and enhancing manufacturers and the public's understanding of new energy vehicles.

\section{Influencing Factors and Model Analysis of Public Purchase of New Energy Vehicles in Guangzhou}

From the in-depth empirical analysis of consumers'demand for new energy vehicles, the investigation of consumer purchase intention, the effect of research are more concentrated, the methods are relatively rich, the empirical evidence of and the impact of policies on consumers' purchase intention.

The research on the promotion and application policy of new energy vehicles is based on Guangzhou City, and mainly adopts the combination of theoretical research and empirical research, the combination of quantitative analysis and qualitative analysis.Using SPSS software to sort out and analyze the collected data. Therefore, the distribution area of online and offline questionnaires is limited to Guangzhou citizens. The distribution targets are targeted and limited to potential car consumers. The place for distributing paper questionnaires on the spot was selected at the car 4s shop. The survey subjects included potential consumers of new energy vehicles and the staff of the car $4 \mathrm{~s}$ shop. The specific situation is as follows:

Table1. Questionnaire distribution and recovery.

\begin{tabular}{|c|c|c|c|}
\hline Project & $\begin{array}{c}\text { Number of } \\
\text { questionna } \\
\text { ires issued }\end{array}$ & $\begin{array}{c}\text { Number of } \\
\text { valid } \\
\text { questionnaires }\end{array}$ & $\begin{array}{c}\text { Effective } \\
\text { recovery } \\
\text { rate }\end{array}$ \\
\hline $\begin{array}{c}\text { Offline } \\
\text { questionnaire }\end{array}$ & 200 & 198 & $99 \%$ \\
\hline $\begin{array}{c}\text { Online } \\
\text { questionnaire }\end{array}$ & 200 & 189 & $94.5 \%$ \\
\hline Total & 400 & 387 & $96.75 \%$ \\
\hline
\end{tabular}

\subsection{Research design}

A total of 387 valid questionnaires were collected in this questionnaire survey. The questionnaire first counted the basic characteristics of the surveyed persons such as gender, age, and educational background. The analysis of the basic characteristics of the surveyed is helpful to further prove the pertinence and rationality of the surveyed samples.

Table2. Characteristics of the overall consumer sample.

\begin{tabular}{|c|c|c|c|c|}
\hline $\begin{array}{c}\text { Variable } \\
\text { situation }\end{array}$ & classification & $\begin{array}{c}\text { Number } \\
\text { of } \\
\text { people }\end{array}$ & percentage & $\begin{array}{c}\text { Cumulative } \\
\text { percentage }\end{array}$ \\
\hline \multirow{2}{*}{ Gender } & Male & 263 & 68 & 68 \\
\cline { 2 - 5 } Age & Female & 124 & 32 & 100 \\
\cline { 2 - 5 } & Under 30 & 116 & 30 & 30 \\
\cline { 2 - 5 } & $31-45$ & 190 & 49 & 79 \\
\cline { 2 - 5 } & O6-60 & 72 & 18.5 & 97.5 \\
\hline \multirow{3}{*}{$\begin{array}{c}\text { Purchasin } \\
\text { g purpose }\end{array}$} & Commuting & 199 & 51.5 & 100 \\
\cline { 2 - 5 } & Weekend play & 112 & 29 & 81.5 \\
\cline { 2 - 5 } & $\begin{array}{c}\text { Long-distance } \\
\text { business trip }\end{array}$ & 76 & 19.5 & 100 \\
\hline \multirow{3}{*}{$\begin{array}{c}\text { Education } \\
\text { backgrou } \\
\text { nd }\end{array}$} & $\begin{array}{c}\text { College and } \\
\text { below }\end{array}$ & 188 & 48.5 & 48.5 \\
\cline { 2 - 5 } & Undergraduate & 174 & 45 & 93.5 \\
\cline { 2 - 5 } & $\begin{array}{c}\text { Master degree } \\
\text { and above }\end{array}$ & 25 & 6.5 & 100 \\
\hline
\end{tabular}

To understand the overall situation of the effect of Guangzhou's new energy vehicle policy on consumers' purchase intentions, the survey focused on "whether they 
will buy new ones" and set the options of "with"or "no"for purchase intentions. Consumers with new energy purchase intentions accounted for The overall $34.7 \%$, the overall purchase intention is low. On the other hand, consumers are worried about the stability of the policy. These reasons all make consumers "wait and see" more than "action" on the source car. The specific situation is as follows in Table 3:

Table3. Statistics of consumer purchase intention.

\begin{tabular}{|c|c|c|c|c|}
\hline \multicolumn{2}{|c|}{} & Frequency & Percentage & $\begin{array}{c}\text { Effective } \\
\text { percentage }\end{array}$ \\
\hline \multirow{3}{*}{$\begin{array}{c}\text { valid } \\
\text { data }\end{array}$} & no & 165 & 42.7 & 42.7 \\
\cline { 2 - 5 } & other & 88 & 22.6 & 65.3 \\
\cline { 2 - 5 } & with & 134 & 34.7 & 100 \\
\cline { 2 - 5 } & total & 387 & 100 & 100 \\
\hline
\end{tabular}

\subsection{Research data analysis}

In order to understand the overall situation of Guangzhou's effect by new energy vehicle policy on consumers' purchase intention, new energy vehicle policy is obtained by summing the three dimensions of the direct economic preferential policies, supporting support policies and indirect economic preferential policies. The original total score is 35 points and the full score is 100 points for conversion processing. The conversion result of the percentile system is divided into three grades. Among them, those with a score of 60 points or less are considered as "minor influence". Those with a score of $60-80$ points are considered as "general influence"and score of 80 points or more are considered as "larger influence".

Table4. Statistics of consumer purchase intention.

\begin{tabular}{|c|c|c|c|c|c|}
\hline $\begin{array}{c}\text { Raw } \\
\text { score }\end{array}$ & Max & $\begin{array}{c}\text { Minimu } \\
\mathrm{m}\end{array}$ & $\begin{array}{c}\text { Mea } \\
\mathrm{n}\end{array}$ & $\begin{array}{c}\text { Standard } \\
\text { deviation }\end{array}$ & $\mathrm{N}$ \\
\hline $7-35$ & 35 & 7 & 27.1 & 10.891 & 387 \\
\hline
\end{tabular}

From the survey on the currency preferential method for the purchase of new energy vehicles, the influence of purchase intention has four dimensions. The new energy vehicle purchase subsidies, purchase tax reductions, charging subsidies, vehicle, vessel tax and toll reductions. The scores of various indicators in the questionnaire are as follows :

Table5. Currency discount survey score.

\begin{tabular}{|c|c|c|c|}
\hline \multicolumn{2}{|c|}{ variable } & Mean & $\begin{array}{c}\text { Standard } \\
\text { deviation }\end{array}$ \\
\hline \multirow{2}{*}{$\begin{array}{c}\text { Currency } \\
\text { discount }\end{array}$} & $\begin{array}{c}\text { Purchase } \\
\text { subsidy }\end{array}$ & 3.42 & 1.024 \\
\cline { 2 - 4 } & $\begin{array}{c}\text { Purchase tax } \\
\text { relief }\end{array}$ & 3.31 & 1.002 \\
\cline { 2 - 4 } & $\begin{array}{c}\text { Charging } \\
\text { subsidy }\end{array}$ & 3.55 & 0.922 \\
\hline & $\begin{array}{c}\text { Vehicle and } \\
\text { vessel tax, toll } \\
\text { reduction and } \\
\text { exemption }\end{array}$ & 3.52 & 0.912 \\
\hline
\end{tabular}

It can be seen that monetary incentives have a positive impact on the public's willingness to purchase new energy vehicles, but the impact is not very high. The scores of these indicators are relatively close, but the two use indicators of charging subsidies, vehicle, vessel tax, toll reduction and exemption have slightly higher scores. It shows that the public is more inclined to use long-term currency discounts than the one-time subsidy.
The survey also investigated the influence of purchase intention from the perspective of new energy vehicle priority incentives. There are four dimensions. Don't limit the purchase of new energy vehicles, unlimited travel numbers, the right to use bus lanes and the establishment of dedicated parking spaces. Various indicators are under investigation. The scores of the questionnaire are as follows:

Table6. Non-monetary priority incentive survey results.

\begin{tabular}{|c|c|c|c|}
\hline \multicolumn{2}{|c|}{ variable } & Mean & $\begin{array}{c}\text { Standard } \\
\text { deviation }\end{array}$ \\
\hline \multirow{4}{*}{$\begin{array}{c}\text { Prioritize } \\
\text { incentive } \\
\text { s }\end{array}$} & $\begin{array}{c}\text { Unlimited } \\
\text { purchase }\end{array}$ & 3.88 & 1.102 \\
\cline { 2 - 4 } & Unlimited number & 4.13 & 0.896 \\
\cline { 2 - 4 } & Dedicated lane & 3.80 & 1.030 \\
\cline { 2 - 4 } & $\begin{array}{c}\text { Dedicated parking } \\
\text { space }\end{array}$ & 3.91 & 1.003 \\
\hline
\end{tabular}

According to the survey score, Priority measures have a positive impact on the public's willingness to purchase new energy vehicles. The public attaches a high degree of priority to incentives. The use of new energy vehicles can have a good influence on the public's willingness to purchase. Among them, the score of the new energy vehicle travel unlimited number indicator is higher than other indicators.

Finally, the impact of new energy vehicle infrastructure construction on the public's willingness to purchase has three dimensions. Namely, the construction of public charging facilities, the construction of direct windows for private charging facilities, the degree of perfection of the online service system are charging facilities.The public attaches great importance to the construction of new energy vehicle infrastructure. In particular, the score of perfection of public charging stations is as high as 4.35 , which shows that the status of infrastructure construction is directly related to the public's willingness to use.

\subsection{Factors hindering the purchase of new energy vehicles}

According to survey statistics, $3.80 \%$ have insufficient knowledge about new energy vehicles, $40.83 \%$ have insufficient technical performance of vehicles and $4.84 \%$ have insufficient purchase subsidies. Supporting facilities $36.33 \%$ are unsound and $14.1907 \%$ have insufficient preferential priority. It can be seen that consumers currently believe that the main factors leading to their reluctance. New energy vehicles are the immature technical performance supporting facilities.

Table7. Factors that are unwilling to buy new energy vehicles.

\begin{tabular}{|c|c|c|}
\hline Factor & Number & Proportion \\
\hline Under-cognition & 14 & $3.81 \%$ \\
\hline Immature technology & 158 & $40.82 \%$ \\
\hline Insufficient subsidies & 19 & $4.88 \%$ \\
\hline $\begin{array}{c}\text { Unsound supporting } \\
\text { settings }\end{array}$ & 138 & $35.63 \%$ \\
\hline Insufficient discountr & 58 & $14.86 \%$ \\
\hline
\end{tabular}




\section{Measures to optimize the path of the innovation ecosystem of Guangzhou's new energy automobile industry and improve the incentive mechanism}

\subsection{Public policy incentives}

Public policy is the policy of government departments to solve social problems has social management. It is the guarantee for solving the problems in the promotion and application of new energy vehicles. The implementation of public policies that reflects the best plan of public governance is a guarantee for improving the efficiency of the promotion and application of new energy vehicles. Public policies reflect the government's will guidance. Promoting the promotion and application of new energy vehicles can effectively promote the standardized scientific .

\subsection{Strengthen support for local enterprises to innovate and improve their competitiveness}

Guangzhou has the background and strong strength to develop automobile technology. It is necessary to give full play to the advantages of Guangzhou Automobile's scale. Integrating the resources of technology research and development, vehicle manufacturing and after-sales service local new energy automobile industry chain. Giving full play to the advantages of all parties, making up for weak links and building a large-scale industrial system of new energy vehicle technology. The development of the new energy automobile industry through formulating preferential policies.

\subsection{Rich priority incentives}

There are a large number of cars in Guangzhou, the difficulty of parking and road congestion during the use of cars, the formulation of incentive policies that new energy vehicles have more priority in the field of use than traditional cars and strengthen the convenience. The market-oriented role of energy vehicles in the use process. On the basis of continuing to implement new energy vehicles without lottery and licensing, speed up the overall promotion and implementation of new energy vehicle special number plates. Increasing the speed of new energy vehicle strengthen the convenience of new energy vehicle registration at home Sex. For roads with traffic congestion, new energy vehicles are given the right to use bus lanes. Parking spaces for new energy vehicles on both sides of urban roads or large-scale commercial centers mark them, adjust the number of parking spaces according to the amount of new energy vehicles stored in a timely manner. The system to avoid being occupied by traditional vehicles.

\section{Conclusion}

As a first-tier city and an automobile industry city in Guangzhou, the promotion and application of new energy vehicles is not satisfactory at the current stage, and the existing supporting policies need to be continuously adjusted and improved. Through investigation and analysis that affect the public's purchase of new energy vehicles, it is concluded that knowledge of new energy vehicles, vehicle performance, monetary subsidies, priority measures. The construction of charging facilities are all factors that positively affect the public's willingness to buy. The construction of charging facilities is the two main factors. Furthermore, it shows that the promotion effect of Guangzhou's new energy vehicle policy is insufficient and needs to be further improved and adjusted. In future research, it is necessary to collect more data, describe the current development of new energy vehicles in Guangzhou . The impact of policy implementation on the promotion and application.

\section{Acknowledgment}

This research was financially supported by the Key Research Platforms and Scientific Research Projects of Guangdong Province in 2018 (Young Innovative Talents) (Grant NO.2018WQNCX257) and Supported by the 2019 school-level scientific research project of Huali College Guangdong University of Technology(Grant NO. HLKY2019-SK-07).

\section{References}

1. Li Xiaomin,Liu Yiran,Jing bolun.Research on the Impact of Industrial Support Policies on the Promotion of New Energy Vehicles in China[J]. Management Review, 2021, 21(06): 1-11.

2. Ou Hongbin. Research on the Promotion and Application Policy of New Energy Vehicles in Guangzhou[D].South China University of Technology, 2018.

3. WuXuebin.Comparison of New Energy Vehicle Promotion Policies in Beijing, Shanghai and Guangzhou Based on the Analytic Hierarchy Process[J]. Journal of Shanghai University (Natural Science Edition),2017,23(06):973-984.

4. Yeung. 'Made in China 2025': the development of a new energy vehicle industry in China[J]. Area Development and Policy,2019,4(1).

5. Yang Tong,Xing Chen,Li Xinyu. Evaluation and analysis of new-energy vehicle industry policies in the context of technical innovation in China[J]. Journal of Cleaner Production,2021,281. 